\title{
Hasil Fungsional Pascaoperasi Pasien dengan Dislokasi Panggul Kongenital pada Kelompok Usia Berjalan
}

\author{
Iwan Hipsa Achmad, Yoyos Dias Ismiarto \\ ${ }^{1}$ Departemen/SMF Orthopaedi dan Traumatologi Fakultas Kedokteran Universitas Padjadjaran \\ Rumah Sakit Dr. Hasan Sadikin Bandung, Indonesia
}

\begin{abstract}
Abstrak
Kasus dislokasi panggul kongenital (DDH) masih terjadi setelah usia berjalan karena terlambat atau tidak terdiagnosis. Pilihan pengobatan untuk DDH setelah usia berjalan adalah prosedur bedah telah menjadi tantangan pada bidang ortopaedi. Tujuan penelitian ini adalah menilai hasil klinis dan radiografi pengobatan bedah DDH setelah usia berjalan. Penelitian ini melibatkan 13 pasien (15 panggul) di Rumah Sakit Dr. Hasan Sadikin Bandung tahun 2012-2015 yang telah dilakukan tindakan operatif pada usia 1 sampai 7 tahun dengan tindakan reduksi terbuka, femoral osteotomi, dan osteotomi panggul. Hasil klinis akhir setelah follow up (rerata 22 bulan) memiliki hasil excellent 5 pasien, good 7 pasien, fair 2 pasien, dan poor satu pasien. Secara radiologi hasilnya adalah Kelas I (excellent) 8 pasien, Kelas II (good) 5 pasien, Kelas III (fair) satu pasien, dan kelas IV (poor) satu pasien. Hasil yang memuaskan adalah 10 pasien secara klinis dan 11 pasien (dinilai dari radiologi). Simpulan, hasil fungsional pasien DDH yang dilakukan perawatan setelah operasi di usia berjalan mayoritas memiliki hasil yang baik.
\end{abstract}

Kata kunci: Dislokasi panggul kongenital, hasil fungsional, usia berjalan

\section{Post-operative Functional Outcome in Walking-Age Patients with Congenital Hip Dislocation}

\begin{abstract}
Cases of developmental dysplasia of the hip (DDH) still occur after walking age because of late or missed diagnosis. The treatment of choice for DDH after walking age is surgical procedure, which has been a challenge in the orthopedic field. The aim of this study was to assess the clinical and radiographic results of surgical treatment of DDH after walking age. The study included 13 patients (15 hips) who underwent surgeries at the age of 1 to 7 years with open reduction, femoral osteotomy, and pelvic osteotomy procedures in Dr. Hasan Sadikin General Hospital Bandung from 2012-2015. The final clinical outcomes at the end of the follow up period (mean $=22$ months) was excellent in 5 patients, good in 7 patients, fair in 2 patients, and poor in one patient. The final radiological results presented Class I (excellent) in 8 patients, Class II (good) in 5 patients, Class III (fair) in one patient, and Class IV (poor) in one patient. The number of patients that had satisfactory outcome was 10 patients clinically and 11 patients radiologically. It is concluded that the functional outcome of DDH patients surgery in walking is mostly good.
\end{abstract}

Key words: DDH, functional outcome, walking age

Korespondensi: Dr. Yoyos Dias Ismiarto, dr., SpOT(K), M.Kes., CCD, Departemen/SMF Orthopaedi dan Traumatologi Fakultas Kedokteran Universitas Padjadjaran/Rumah Sakit Dr. Hasan Sadikin, Jalan Pasteur No. 38 Bandung, Jawa Barat 40161, Telepon: (022) 2034953/55, Email: yosismiarto@yahoo.com 


\section{Pendahuluan}

Dislokasi panggul kongenital (DDH) merupakan kelainan kongenital terjadi dislokasi pada panggul karena asetabulum dan femoral head tidak berada pada tempat seharusnya. Tidak semua dislokasi panggul dapat direduksi. Dalam subluksasi panggul, kepala femoralis sebagian bergeser posisinya, tetapi masih terdapat kontak dengan asetabulum yang masih tersisa. ${ }^{1}$

Insidensi DDH adalah 1/1.000 pada angka kelahiran. Wanita mempunyai angka kejadian yang tinggi bila dibanding dengan pria dengan rasio 7:1. Panggul kiri lebih sering terkena dibanding dengan kanan. Tidak ada penyebab pasti DDH, namun beberapa faktor risiko telah diidentifikasi, di antaranya kelenturan ligamen, posisi pada saat dalam kandungan, posisi pada saat dilahirkan, dan predileksi ras. Penyebab DDH bersifat multifaktorial dan dipengaruhi oleh hormon dan genetik. ${ }^{2}$

Perkembangan normal pada panggul anak bergantung pada stabilitas panggul kepala femoralis di asetabulum. Sendi panggul tidak akan berkembang dengan baik jika tetap tidak stabil dan secara anatomi abnormal dengan usia berjalan. $^{3}$

Proses berjalan dapat didefinisikan sebagai rangkaian gerakan ekstremitas yang mampu terkoordinasi dan terkendalikan dengan baik untuk memajukan tubuh dari tempat ke tempat lain disertai dengan pengeluaran energi. Sebagian besar anak dapat mulai berjalan dari 11 hingga 15 bulan, tetapi laju perkembangannya sangat bervariasi. Pada usia 18 bulan jika anak tidak dapat berjalan maka dianggap sebagai proses keterlambatan untuk berjalan. Dislokasi panggul kongenital merupakan penyebab penting dari kecacatan pada masa anak-anak. Tanpa deteksi maupun skrining, dislokasi panggul kongenital biasanya ditemukan secara klinis setelah usia

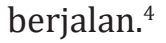

Pengobatan DDH di kelompok usia berjalan biasanya dilakukan pembedahan karena fakta menyatakan terdapat perubahan patologis pada usia ini sebagai kontrakur berat pada otot, tendon dan kapsul sekitar panggul, meningkatkan penyempitan asetabulum, femoral anteversion yang berlebihan, hipertropoid labrum, pulvinar (fibrofatty tissue) berlebihan, arah yang salah pada asetabulum akan membuat reduksi tertutup sangat sulit dan dapat menyebabkan nekrosis avaskular dari femoral head atau dislokasi yang berulang. Penanganan untuk DDH ini dilakukan secara operatif pada usia lebih dari 18 bulan dengan tindakan reduksi terbuka, osteotomi femoral maupun osteotomi dari panggul. Hasil fungsional secara klinis dan radiologis merupakan hal penting yang dievaluasi setelah tindakan operatif tersebut pada anak usia berjalan. ${ }^{2,5}$

\section{Metode}

Penelitian ini dilakukan pada penderita DDH di Rumah Sakit Dr. Hasan Sadikin Bandung. Pasien yang didiagnosa DDH dari tahun 2012 hingga 2015 terdapat 13 pasien (15 panggul). Panggul kanan sebanyak 9, dan panggul kiri sebanyak 6 . Usia termuda adalah 14 bulan, sedangkan usia tertua adalah 90 bulan dengan rerata usia 36.3 bulan.

Seluruh pasien pada pada penelitian ini telah dilakukan pemeriksaan fisis pada akhir kunjungan. Tes trendelenburg, limping, hip stability posisi terlentang, ada atau tidak ada deformitas dan batas gerak dinilai pada kunjungan terakhir. Evaluasi klinis dinilai dengan kriteria MacKay dan Harris Hip score (Tabel 1). ${ }^{6}$

$X$-ray antero-posterior (AP) pada pelvis dipergunakan untuk menilai acetabular index (AI) dan center-edge angle (CEA) preoperatif, posoperatif, dan akhir dari follow-up. Nilai acetabular index lebih dari $30^{\circ}$ dianggap tidak normal dan indikasi terjadi impending dislokasi. Seluruh pasien pada penelitian ini memiliki AI di atas $30^{\circ}$ yang dianggap tidak normal. Evaluasi radiologi pada akhir follow-up dinilai menggunakan Severin radiographic criteria (Tabel 2). ${ }^{6}$

Seluruh pasien telah dilakukan penanganan operatif reduksi terbuka, pelvic osteotomi, dan atau pemendekan tulang femur diikuti dengan imobilisasi menggunakan hip spica cast selama 8 minggu. Tindakan operatif dilakukan dengan insisi anterior panggul (Smith-Peterson), kemudian dilakukan reduksi secara terbuka, dievaluasi jika terdapat anteversion femoral maka dilakukan pemendekan tulang femoral dan dilakukan pemasangan plate and screw. Osteotomi pada panggul dilakukan untuk memenuhi cakupan anterior dan anterolateral dari panggul.

\section{Hasil}

Hasil klinis akhir setelah follow up (rerata 22 bulan) memiliki hasil excellent 5 pasien, good 7 pasien, fair in 2 pasien, dan poor 1 pasien. Secara radiologi hasilnya adalah kelas I (excellent) 
Iwan H. Achmad dkk.: Hasil Fungsional Pascaoperasi Pasien dengan Dislokasi Panggul Kongenital pada Kelompok Usia Berjalan

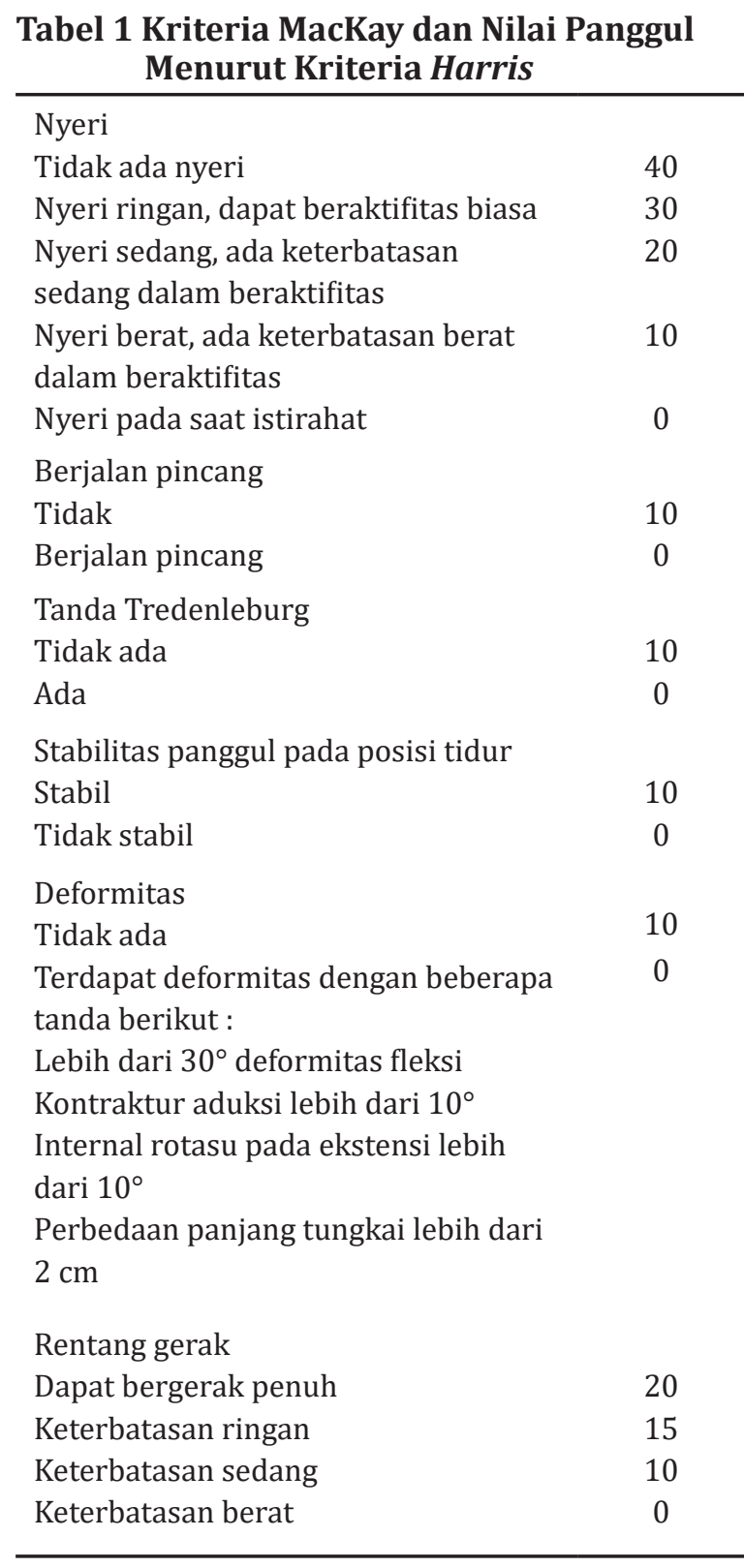

Tabel 3 Keseluruhan Hasil Klinis Akhir

\begin{tabular}{lc}
\hline Hasil Klinis Akhir & $\begin{array}{c}\text { Frekuensi } \\
(\mathbf{n}=\mathbf{1 5})\end{array}$ \\
\hline Excellent & 5 \\
Good & 7 \\
Fair & 2 \\
Poor & 1 \\
\hline
\end{tabular}

8 pasien, kelas II 5 pasien, Kelas III (fair) 1 pasien dan kelas IV (poor) 1 pasien. Hasil yang memuaskan adalah 10 pasien secara klinis dan 11 pasien dinilai dari radiologi. Hasil yang tidak memuaskan adalah $3(20 \%)$ pasien secara klinis dan secara radiologi $2(13,4 \%)$ pasien.

Acetabular index (AI) menurun di semua panggul pada evaluasi akhir. Rerata AI preoperatif adalah $37,5^{\circ}$ Pada akhir follow-up menurun menjadi rerata $27,4^{\circ}\left(20^{\circ}-30^{\circ}\right)$. Center edge angle (CEA) meningkat pada seluruh pasien di akhir follow-up kecuali 2 pasien $\left(10^{\circ}, 15^{\circ}\right)$. CEA preoperatif negative di seluruh pasien. Rerata CEA posoperatif adalah $32,5^{\circ}\left(10^{\circ}-50^{\circ}\right)$.

\section{Pembahasan}

Pada anak usia berjalan dengan DDH, pengobatan dengan tindakan operasi sering disarankan sebagai pilihan pertama pengobatan, walaupun

Tabel 4 Hasil Akhir Radiologis

\begin{tabular}{lc}
\hline Kriteria Severin & $\begin{array}{c}\text { Frekuensi } \\
(\mathbf{n = 1 5})\end{array}$ \\
\hline Kelas I & 8 \\
Kelas II & 5 \\
Kelas III & 1 \\
Kelas IV & 1 \\
\hline
\end{tabular}

Tabel 2 Kriteria Radiografi Menurut Severin

\begin{tabular}{ll}
\hline Kelas I (excellent) & Panggul normal dengan sudut center-edge $>25^{\circ}$ \\
Kelas II (good) & $\begin{array}{l}\text { Reduksi konsentrik, bentuk kepala abnormal, leher panggul atau } \\
\text { asetabulum dengan CEA }>25^{\circ}\end{array}$ \\
Kelas III (fair) & Displastik panggul dengan kelainan pembentukan asetabulum \\
& hip. CEA $<20^{\circ}$, tidak ada subluksasi \\
Kelas IV (poor) & Subluksasi (kepala panggul bergeser ke kranial dan lateral) \\
Kelas V (poor) & Kepala panggul berartikulasi dengan asetabulum palsu \\
Kelas VI (poor) & Dislokasi keseluruhan panggul \\
\hline
\end{tabular}



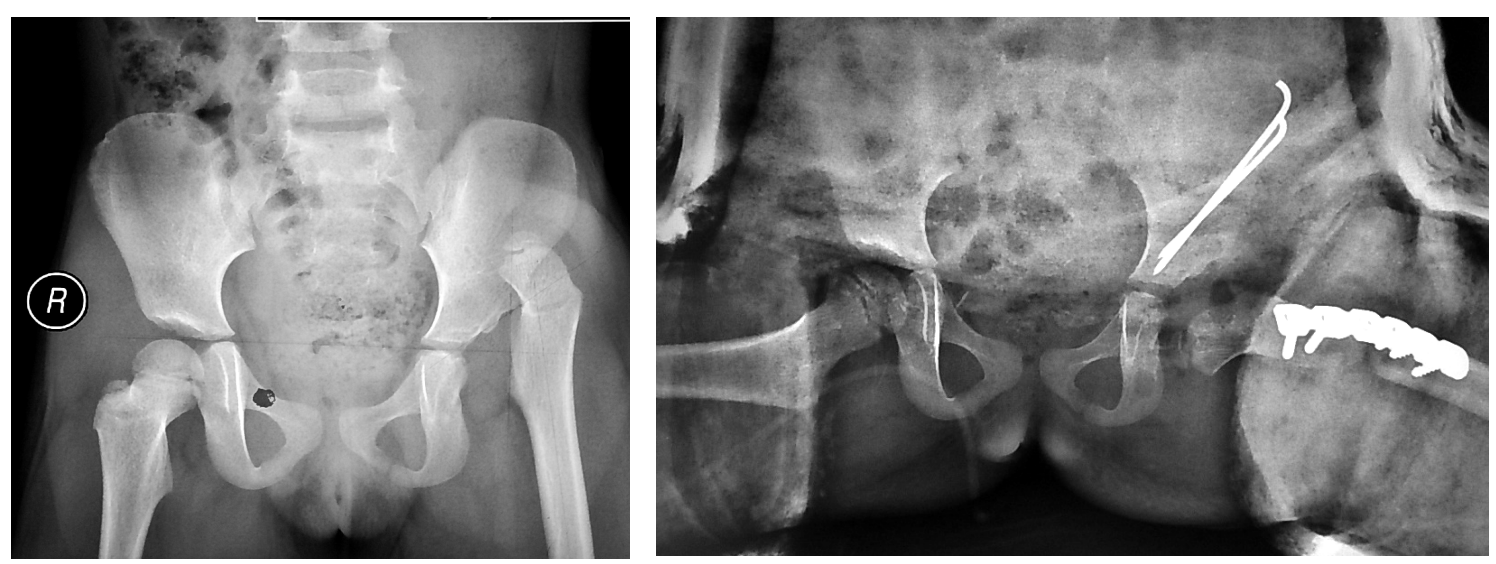

Gambar Radiologi Preoperatif dan Post Operatif Tindakan Reduksi Terbuka dengan Pemendekan Tulang Femoral Dan Pelvic Osteotomi

jenis penanganannya masih belum diketahui dengan jelas. Reduksi dislokasi panggul dengan atau tidak disertai osteotomi menghasilkan perkembangan panggul yang baik pada anak usia di atas 18 bulan. $^{7}$

Setelah anak mulai dapat berjalan terdapat kecenderungan penderita DDH mengalami interposisi jaringan lunak seperti di ligamen, labrum, dan kapsul sendi panggul. Oleh karena itu, diperlukan reduksi terbuka. ${ }^{8}$

Beberapa investigasi dievaluasi pada hasil fungsional jangka panjang dan hasil radiologi pada tindakan operatif DDH di usia berjalan. Sebagian besar memakai beberapa kombinasi penanganan operatif dan juga perbedaan pada pemilihan pasien, lamanya follow-up, dan juga klasifikasinya. Hal ini membuat sulit jika hasil mereka dibanding dengan dengan penelitian kami.

Heesakkers dkk. ${ }^{7}$ pada penelitianya telah menyatakan 32 panggul dari 22 pasien di atas usia 2 tahun ditangani dengan metode operasi serta melaporkan hasil yang memuaskan secara klinis dan radiologis sebanyak 73\%. Rocha dkk. ${ }^{8}$ menyimpulkan penggunaan teknik Salter osteotomi dengan reduksi terbuka dan kapsuloplasti menjadi pilihan yang baik untuk perawatan DDH setelah anak mulai berjalan dengan hasil klinis dan radiologis yang memuaskan mencapai 88,9\%. Pada penelitian ini hasil klinis dan radiologis sebanyak 80\%.

El-Sayed dkk. ${ }^{9}$ melaporkan hasil tindakan operasi baik osteotomi dengan teknik Salter atau Dega menghasilkan nilai klinis excellent dan good pada 93 panggul $(85,3 \%)$. Bhuyan ${ }^{10}$ pada penelitiannya mengevaluasi 25 pasien (30 panggul) dengan tindakan operasi satu tahap menghasilkan hasil klinis excellent dan good sebanyak 27 panggul serta Severin score I dan II pada 25 panggul $(83,3 \%)$. Pada penelitian ini hasil tindakan operasi yang dinilai dengan Severin score I dan II mencapai 86,6\%.

Yagmurlu dkk.11 mempergunakan tindakan operasi dengan reduksi terbuka, pemendekan femoral, triple pelvic osteotomi, atau salter osteotomi pada 21 pasien (27 panggul). Hasilnya memuaskan, $74 \%$ pasien menggambarkan hasil baik secara radiologis dan $63 \%$ baik secara klinis. Pada penelitian ini tindakan reduksi terbuka disertai pemendekan femoral dan salter osteotomi sebanyak $70 \%$ pasien memiliki hasil baik secara klinis dan $80 \%$ secara radiologis.

Penanganan operatif pada DDH di usia berjalan merupakan suatu metode yang sangat baik. Untuk keberhasilan operasi reduksi terbuka dengan menghilangkan soft tissue yang menganggu reduksi sehingga mendapatkan posisi optimal dari femoral head ke asetabulum. Koreksi osteotomi asetabular displasia sangat penting untuk mendapatkan reduksi yang stabil pada panggul. Pemendekan femur dilakukan pada kasus terdapat reduksi yang sulit untuk menghindari tekanan femoral head dan juga berkembangnya nekrosis avaskular.

Tindakan operatif pada DDH terhadap hasil fungsional anak kelompok usia berjalan memiliki hasil yang baik secara klinis maupun radiologis sehingga dapat meningkatkan kualitas hidup pasien.

\section{Daftar Pustaka}

1. Kotlarsky P, Haber R, Bialik V, Eidelman M. 
Developmental dysplasia of the hip: what has changed in the last 20 years?. World J Orthopedics. 2015;6(11):886.

2. Solomon L, Ganz R, Leunig M, Monsell F, Learmonth. The hip. Dalam: Solomon L, Warwick D, Nayagam S, Apley A, penyunting. Apley's system of orthopaedics and fractures. Edisi ke-9. London: Hodder Education; 2010. hlm. 498-504.

3. Schwend RM, Shaw BA, Segal LS. Evaluation and treatment of developmental hip dysplasia in the newborn and infant. Pediatr Clin North Am. 2014;61:1095-107.

4. Alkattan H. Developmental hip dysplasia and delayed walking. Iraqi J Community Med. 2012;25(1):44-8.

5. Mootha A, Saini R, Dhillon M, Aggarwal S, Wardak E, Kumar V. Do we need femoral derotation osteotomy in DDH of early walking age group? A clinico-radiological correlation study. Arch Orthopaedic Trauma Surg. 2009;130(7):853-8.

6. Abdullah E, Razzak M, Hussein H, El-Adwar K, Abdel-RazekYoussef A. Evaluation of the results of operative treatment of hip dysplasia in children after the walking age. Alexandria J Med. 2012;48(2):115-22.

7. Heesakkers N, Witbreuk M, Besselaar P, Van Der Sluijs J. Retrospective radiographic evaluation of treatment results of developmental dysplasia of the hip in walking-age children. J Pediatr Orthopaedics B. 2013;22(5):427-31.

8. Rocha VL, Marques GL, Silva LJ, Bernardes TAM, Moraes FB. Clinical and radiographic medium-term evaluation on patients with developmental dysplasia of the hip, who were submitted to open reduction, capsuloplasty and Salter osteotomy. Rev Bras Ortop. 2014;49:51-5.

9. El-Sayed M, Ahmed T, Fathy S, Zyton $\mathrm{H}$. The effect of Dega acetabuloplasty and Salter innominate osteotomy on acetabular remodeling monitored by the acetabular index in walking DDH patients between 2 and 6 years of age: short- to middle-term follow-up. J Child Orthop. 2012;6:471-7.

10. Bhuyan BK. Outcome of one-stage treatment of developmental dysplasia of hip in older children. Indian J Orthop. 2012;46(5):54855.

11. Yagmurlu MF, Bayhan IA, Tuhanioglu U, Kilinc AS, Karakas ES. Clinical and radiological outcomes are correlated with the age of the child in single-stage surgical treatment of developmental dysplasia of the hip. Acta Orthop Belg. 2013;79(2):159-65. 